\title{
Conversion of Degradable Solid Waste into Alternative Energy using Local Wastes as a Binder, Case of Southwestern Ethiopia
}

\author{
Abreham Bekele Bayu ${ }^{1 *}$, Ketema Beyecha Hundie ${ }^{2}$ \\ ${ }^{1}$ School of Chemical Engineering, Jimma Institute of Technology, Jimma University, Jimma, Ethiopia \\ ${ }^{2}$ School of Chemical Engineering, Jimma Institute of Technology, Jimma University, Jimma, Ethiopia \\ *Corresponding author : abreham.bekele@ju.edu.et
}

Article history

\begin{tabular}{llll} 
Received & Received in revised form & Accepted & Available online \\
05 August 2020 & 06 December 2020 & 31 December 2020 & 31 December 2020 \\
\hline
\end{tabular}

05 August $2020 \quad 06$ December $2020 \quad 31$ December $2020 \quad 31$ December 2020

\begin{abstract}
The objective of this research is to produce high quality of charcoal from the most known local wastes as a binder. The solid waste was collected from Southwestern Ethiopia and the production of charcoal briquette based on different binder preparation. The local wastes like sawdust and paper were used as a binder comparing with starch as a standard binder. The result obtained by using sawdust shows better burning time and less smoke comparing with using paper as a binder next to using starch as a binder. The proximate analysis result obtained for degradable solid waste was its density, percentage of moisture, volatile matter, ash, fixed carbon, and caloric value of $16.73 \mathrm{~kg} / \mathrm{m}^{3}, 17.81 \%$, $67.56 \%, 4.78 \%, 9.85 \%$, and $18.39 \mathrm{MJ} / \mathrm{kg}$ respectively. In the same way, fuel briquette using sawdust as a binder was characterized for its density, percentage of porosity, weight index, shatter resistance, moisture content, volatile matter content, ash content, fixed carbon content, and caloric value which is $750.06 \mathrm{~kg} / \mathrm{m}^{3}, 29.05 \%, 92.38 \%, 9.87 \%, 29.6 \%$, $3.56 \%, 56.97 \%$ and $27.38 \mathrm{MJ} / \mathrm{kg}$ respectively. Using sawdust is better than using paper as a binder since the briquette produced by using sawdust as a binder shows less smoke and higher burning time. This shows that it is possible to convert solid wastes into fuel briquettes using local wastes as binders.
\end{abstract}

Keywords: degradable waste, fuel briquette, energy, environment

\section{Introduction}

The generation rate of solid waste in Southwestern Ethiopia is expressed as the amount of waste $(\mathrm{kg})$ generated by one person per day will be the total waste collected in nine days divided by the total number of people and it will be about $0.130 \mathrm{~kg} / \mathrm{ca} / \mathrm{da}$ [1]. Solid waste control and management are some of the major problems in many developing countries like Ethiopia [2]. Solid wastes from households, agroindustries, and food industries dumped in open lands or accumulated in open-dumping sites is one of the major problems in Ethiopian cities [3]. Studies made in Ethiopian cities indicated that inadequate solid waste management has resulted in the accumulation of solid waste on open land [4]. However, as the age of Southwestern Ethiopia is very old, waste management practice is still now inappropriate consideration for environmental and public health protection aspects [5]. The solid waste is simply dumped out into the environment and which causes people to photogenic health problem [6].

Local wastes are available in the environment which can be used as a binder like Sawdust and waste paper. Thus there is much volume of sawdust wastes from wood workshops and paper as waste from education sectors like higher educations in Ethiopia [7]. The characteristics that may be used in deciding solid waste management are color, voids, and shape of

Vol. 5 No. 3, 134-141 components, optical property, magnetic properties, and electric properties [8]. The important chemical properties measured for solid waste are moisture content, volatile matter content, ash content, fixed carbon content, fusing point of ash content, calorific value content, percentage of carbon, hydrogen, oxygen, sulfur, and ash [9].

The proximate analysis of degradable waste aims to determine the content of moisture, the content of volatile matter content of ash, and the content of fixed carbon [10]. The Ultimate analysis determination of the waste of the degradable waste aims to analyze the content of its carbon, hydrogen, oxygen, sulfur, and ash [11]. From the research literature conducted, the percentage of carbon and nitrogen in food waste is $54 \%$ and $0.69 \%$, respectively [12]. These values vary somewhat from the ultimate values which are $49 \%$ and $2.8 \%$ for carbon and nitrogen, respectively [13].

Biodegradable materials can be used as an alternative renewable and carbon-neutral raw material for the production of energy alternatives [14]. There is a shortage of energy and there is the need to source alternative forms of energy, which is different from conventional types. According to information found from the municipality of Southwestern Ethiopia, 55\%, $33 \%$, and $19 \%$ of the waste generated from the town are degradable, disposable, and recyclable respectively [15][16]. During solid waste management, the

http://dx.doi.org/10.22135/sje.2020.5.3.134-141

134 
characteristics of wastes are determined for color, voids, the shape of components, optical property magnetic properties, and electric properties [17]. Ultimate analysis of waste aims to analyze the content of carbon, hydrogen, oxygen, sulfur, and ash [18]. These values vary somewhat from the ultimate values which are $48 \%$ and $2.6 \%$ for carbon and nitrogen respectively [19]. The objective of this research article is to convert Southwestern Ethiopia's degradable solid waste component into fuel briquette by using local wastes like sawdust and paper as a binder for a better environmental pollution control mechanism. Besides, sorting and characterizing Southwestern Ethiopia degradable solid waste, converting Southwestern Ethiopia degradable solid waste to fuel briquette using local wastes as a binder, characterizing fuel briquette produced by using local wastes as a binder, and comparing the better waste binder for fuel briquette production were accomplished.

\section{Materials and Methods}

\subsection{Materials}

The types of equipment used for this research were carbonizer for carbonizing charcoal briquette, grinder for grinding for size reduction, dryer (sunlight) for drying of charcoal briquette, mixer for mixing binder and carbonized charcoal, sieve for the screening of ground charcoal, manual press molding machine, oven for characterization of BMSW and charcoal briquette, and oxygen bomb calorimeter for characterization of charcoal briquette. The ingredient used for this study as a binder was starch, sawdust, and paper. Water was used for binder preparation and mixing, and degradable solid waste as raw material.

\subsection{Methods}

\subsubsection{Sample Preparation}

The solid waste essentially includes different kinds of individuals household waste like wood, sawdust, paper, plastic, bottle, unsold of charcoal recovered from the points of sale. Those wastes were sorted to remove plastic, metal, glass bottle and textiles, and any other form of non-degradable municipal waste.For this research $80 \mathrm{~kg}$ of samples were collected from Jimma City.

\subsubsection{Experimental variable and analytical procedures}

The experimental procedures: At the first stage the collected solid waste was sorted to its variety. The sorted degradable solid waste was then allowed to dry for further size reduction. The size of degradable solid waste was reduced and allowed for carbonization at $105^{\circ} \mathrm{c}$ in the furnance. Mean while the binder was prepared from local wastes like sawdust and paper. The next step was mixing of degradable solid waste charcoal with those binders. The mixed charcoal briquette was alloed to put in a mold. The final stage was determination of the quality of charcoal briquite of using sawdust and paper as a binder compared with the standard one which is starch.

\subsubsection{Characterization of degradable solid waste}

Proximate analysis is the determination of wastes to determine its density, content of moisture, the content of ash, and content of volatile matter. The density of the degradable solid waste sample was determined by weighing an empty cylindrical container of known volume and then carefully filled with the DMSW sample.

$\rho=\frac{\text { DMSW }}{\text { Vcon }}$

Where " $\rho$ " is the density of degradable municipal solid waste in $\left(\mathrm{g} / \mathrm{cm}^{3}\right)$, DMSW is the mass of degradable solid waste in $(\mathrm{g})$ and $\mathrm{V}_{\text {con }}$ is the volume of the container $\left(\mathrm{cm}^{3}\right)$. The content of moisture is determined by weighing a portion of a sample and oven drying it at $105{ }^{\circ} \mathrm{C}$ for three hours.

$\mathrm{MC}(\%)=\mathrm{B} / \mathrm{A} * 100$

Where $\mathrm{MC}$ is the content of moisture, $\mathrm{A}$ is the mass of the sample before drying in $(\mathrm{g})$ and $\mathrm{B}$ is the change in weight of the sample before and after drying in the oven. The content of volatile matter of degradable municipal solid waste was determined by allowing the sample in the furnace until the same weight was obtained. Then it was being placed in a furnace at a temperature of $550^{\circ} \mathrm{C}$ for 10 minutes and weighing after to obtain the difference in weight. The percentage of volatile matters was computed by using the equation:

$\mathrm{VM}(\%)=\left(\frac{\mathrm{W} 3-\mathrm{W} 2}{\mathrm{~W} 2}\right) * 100$

Where, VM $(\%)=$ percentage volatile matter of BMSW, W2 = furnace dried sample weight of BMSW, $\mathrm{g}$ and $\mathrm{W} 3$ =change in weight of furnace dried BMSW before and after transfer to the furnace. For the determination of percentage ash content, the sample of the degradable solid waste was allowed in an.oven till the same weight was detected. The oven-dried sample was then placed into the furnace at a temperature of $900^{\circ} \mathrm{C}$ and left for about 30 minutes.

$\mathrm{AC}(\%)=\left(\frac{\mathrm{W} 2}{\mathrm{~W} 1}\right) * 100$

Where, $\mathrm{W} 1=$ Initial weight of the oven-dried sample $(\mathrm{g}), \mathrm{W} 2=$ weight of ash $(\mathrm{g})$ and $\mathrm{AC}(\%)=$ percentage ash content. The fixed carbon of a fuel is the percentage content of carbon present for combustion.

http://dx.doi.org/10.22135/sje.2020.5.3.134-141 
Fixed carbon indicates the proportion of char that remains after the devolatilization phase. The percentage of content fixed carbon of briquettes was calculated according to Sotannde et al. [20] by subtracting the sum of PVM and PAC from 100. The same process was repeated until the completion of the samples by using the following equation.

$$
\mathrm{FC}=100(\mathrm{MC}+\mathrm{VM}+\mathrm{AC})
$$

Where, $\mathrm{FC}=$ the percentage of fixed carbon, $\mathrm{MC}=$ moisture content in percentage, $\mathrm{VM}=$ percentage content of volatile matter, and $\mathrm{AC}=$ Percentage content of ash. The calorific value presents the energy content of the fuel. According to Roberts et al. [21], it is the characteristics of biomass fuel that relays upon its chemical constitute and percent of moisture content. The most advantageous fuel characteristics are its calorific or heat value.

$\mathrm{Qc}=\left(\mathrm{ET}-\mathrm{e}^{1}-\mathrm{e}^{2} \mathrm{e}^{3}\right) / \mathrm{m}$.

Where, $\mathrm{Q} c=$ heat of combustion (gross), $\mathrm{T}=$ temperature rise (observed), $\mathrm{E}=$ equivalent energy of the calorimeter being used, $\mathrm{e}^{1}=$ Heat generated by burning the nitrogen portion of the air trapped in the bomb to form nitric acid, $\mathrm{e}^{2}=$ Heat produced by the formation of sulfuric acid from the reaction of sulfur dioxide, water, and oxygen, $\mathrm{e}^{3}=$ heat produced by the cotton thread and heating wire where ' $m$ ' $=$ mass of the sample. The gross caloric value was calculated with the following equation number -7 as below.

$\mathrm{GCV}(\mathrm{MJ} / \mathrm{Kg})=37: 777-0.647 \mathrm{M}-0.387 \mathrm{~A}-0.089 \mathrm{VM}$ $\mathrm{R}^{2=} 0.97$.

Where GCV=gross caloric value, $\mathrm{m}=$ content of moisture, $\mathrm{A}=$ content of ash, $\mathrm{VM}=$ content of volatile matter, and $\mathrm{R}=$ coefficient of determination. Sorted waste contains many ingredients like food waste, chatt leaf and stalk, and other degradable waste which contain a high amount of moisture; then to reduce the moisture content of solid waste, it was allowed to sunlight until dried. The sun-dried degradable municipal solid waste was crushed manually. The crushed degradable was then added to carbonized for further processing. After drying the degradable municipal waste was carbonized by using the furnace. A fire port at the lower entrance of the furnace and light through the wicks. At the early stage of the carbonization process, the lid allowed open for not more than 10 minutes since the volatile gases may escape out. After that properly sealed to prevent oxygen from entering. Since the lid was tithed perfectly. The degradable solid waste was left to carbonize for three hours at $250^{\circ} \mathrm{C}$. The dried raw materials were ground to smaller particles and screened using a sieve. The sieved pulverized charcoal was weighed and prepared.

Vol. 5 No. 3, 134-141

\subsubsection{Binder Preparation}

ojs.pps.unsri.ac.id

To meet the proposed target the starch was used as a standard binding material. Local wastes like sawdust and paper were used as binders in this study. The binder materials were used for strengthening the fuel briquettes. The binder was prepared for three binding materials separately i.e for starch, sawdust and paper by dissolving $150 \mathrm{~g}$ of binding materials (starch, sawdust, and paper) separately in $100 \mathrm{~mL}$ of cold water to form a paste and after $500 \mathrm{~mL}$ of water was put to boil. The obtained paste was allowed to mix with the boiling water and gently stirred till the smooth homogeneous solution was observed. In the same way, the binders were prepared from local wastes like sawdust and paper.

\subsubsection{Briquetting charcoal (Compaction)}

The starch bonded, the sawdust bonded and paper bonded carbonized solid waste were pressed in a manual cylinder mold for the production of briquette fuel. Totally nine molds were prepared. i.e three molds for every three binders. The prepared mold briquettes were allowed to dry in the sun for 2 days. The produced briquettes were collected and dried under the sunlight, and after were packed in a plastic bag for further analysis.

\subsubsection{Characterization of charcoal briquette}

The characteristics like density, porosity index, shatter resistance, the content of volatile matter, the content of ash, the content of fixed carbon, and gross calorific. The value content of the degradable solid waste briquettes was investigated. According to Chandrappa et al. [8], it is defined as the mass of packing of the molecules of the substance divided by its volume. The weights of briquettes were determined in the laboratory using a digital balance. Volumes of briquettes were determined by a simple calculation based on the direct measurement of height and diameter of the briquettes since briquettes were cylindrical. The volume was evaluated using.

$\rho b r=\frac{M b r}{V b r}$
$V b r=\pi R^{2} H$

Where, $\mathrm{R}=$ briquette radii, $\mathrm{cm}, \mathrm{H}=$ length of the briquette, $\mathrm{cm}, \mathrm{Mbr}=$ weight of charcoal briquettes in $\mathrm{g}, \mathrm{Vbr}=$ briquettes volume, $\mathrm{cm}^{3}, \pi=$ mathematical constant i.e. 3.14 and $\rho b r=$ density of charcoal briquette, $\mathrm{g} / \mathrm{cm}^{3}$. The property for the porosity of charcoal briquettes was determined based on the amount of water absorbed by each sample. In such a way a pre-weighed charcoal briquette was allowed to immerse in water for not more than 30 seconds. Then the charcoal briquettes were taken out from the water and reweighed to obtain the wet weight of briquette. The mass of water in the briquette

http://dx.doi.org/10.22135/sje.2020.5.3.134-141

136 
was determined by reducing the dry weight of the briquette from the wet weight of the briquette. The porosity index was obtained by dividing the mass of water absorbed into the mass of the briquette immersed in water. Similarly, another batch was introduced, and the same way the process was repeated until the completion of all samples. Then after the porosity index is obtained by using;

$\operatorname{Pi}(\%)=\frac{(W w-W s)}{W s} * 100$.

Where, $\mathrm{Pi}=$ porosity index, $\mathrm{Ws}=$ dry sample weight of briquette $(\mathrm{g})$, and $\mathrm{Ww}=$ wet sample weight of the charcoal briquette after immersed in water $(\mathrm{g})$. According to Zhang $\mathrm{J}$ and Guo Y [22], each briquette sample was allowed for the test to drop from a height of $2 \mathrm{~m}$ onto concrete five times. The durability of charcoal briquette can be obtained as the ratio of the final weight of the charcoal briquette retained after five drops to the initial weight of the charcoal briquette. The fraction of the briquette that retained shattered was used as an index for briquette durability.

$\mathrm{WL}(\%)=\frac{\mathrm{W} 1-\mathrm{W} 2}{\mathrm{~W} 1} * 100$

SR $(\%)=100-W L$

Where WL $(\%)=$ percentage weight loss, $\mathrm{W} 1=$ mass of briquette before shattering $(\mathrm{g})$, W2 $=$ mass of briquette after shattering (g) and SR $(\%)=$ percentage shatter resistance.

The percentage of the moisture of the charcoal briquette can be obtained by weighing a part of a sample in an oven drying for $105{ }^{\circ} \mathrm{C}$ for three hours. The weight change was used to detect the briquette's moisture content using the following relation.

$\mathrm{MC}(\%)=\frac{\mathrm{B}}{\mathrm{A}} * 100$

Where MC is moisture content, $\mathrm{A}$ is the mass of the sample before drying, $g$, and B is the change in weight of the sample before and after drying in the oven. According to [13] the volatile matter refers to the part of a biomass matter that is released as volatile gases. During combustion, most of the solid waste was volatile and burn as gas in the cookstove this implies the high volatile content of biomass material. The percentage volatile matter of the briquettes was determined by a portion of a briquette will be kept in an oven until a constant weight of the sample is obtained. The oven-dried sample was kept in the muffle furnace at a temperature of $550{ }^{\circ} \mathrm{C}$ for 10 minutes. After which the volatile matter in it was have allowed to escape, the crucible allowed to cool Vol. 5 No. 3, 134-141 down in a desiccator and weighed to obtain the mass of volatile parts of the sample i.e the change in mass of the sample before and after kept to the furnace.

$\mathrm{VM}(\%)=\frac{\mathrm{W} 2-\mathrm{W} 3}{\mathrm{~W} 2} * 100$

Where, $\mathrm{VM}(\%)=$ volatile matter percentage, $\mathrm{W} 2$ $=$ oven dried mass of the sample, $\mathrm{g}$ and $\mathrm{W} 3=$ mass of the oven-dried sample after heating in a furnace, g. All chemical breakdown of a biomass fuel produces a solid residue, which in cases can be called ash. The ash can cause problems for the thermo-chemical conversion process, and particularly for combustion because some chemical compounds in the ashcan react to form slag. When biomass is used as fuel in boilers the amount of ash is an important data since at high temperatures it can melt and cause scaling of equipment. The residual ash is undesirable, so the lower level of ash is the best fuel quality. Ash is expected to have values for commercial fuels from $0.7 \%$ to $9.9 \%$, energy crops from $1 \%$ to $9.8 \%$, cereals from $1.8 \%$ to $4.8 \%$, and industrial waste from $0.4 \%$ to $22.6 \%$. According to García R et al. [27], general values may appear in a range from levels below 5-20\%. A portion of a sample was placed in an oven until it is free of moisture. The dried charcoal briquette sample was then allowed to place in a pre-weighed crucible. This was being transferred into the furnace at a temperature of $800^{\circ} \mathrm{C}$ and left for about 30 minutes. During such the sample was turned to white ash. Then, the crucible was be put to desiccators and then cooled.

After cooling the crucible was reweighed to obtain the mass of ash. The same procedure was repeated until the completion of the samples. The ash content was calculated by dividing the weight of ash by that of the weight of the dry sample and will be determined by:

$\mathrm{PAC}=\left(\frac{\mathrm{W} 2}{\mathrm{~W} 1}\right) * 100$

Where, W1 = oven dried sample weight $(\mathrm{g}), \mathrm{W} 2=$ dried sample weight after complete combustion (g), $\mathrm{PAC}=$ ash content percentage.

The Carbon content refers to the percentage of carbon present in a particular sample. Essentially, the fixed carbon of a fuel is the percentage of carbon available for combustion. This is not equal to the total amount of carbon in the fuel (the ultimate carbon) because there is also a significant amount that was released as hydrocarbons in the volatiles. Fixed carbon indicates the proportion of char that remains after the devolatilization phase. According to Ikelle et al. [23], the percentage fixed carbon of briquettes was calculated by subtracting the sum of MC, VM, and AC from 100. The procedure was

http://dx.doi.org/10.22135/sje.2020.5.3.134-141 
repeated again and again until the completion of the samples.

$\mathrm{FC}(\%)=100(\mathrm{PMC}+\mathrm{PAC}+\mathrm{PVM})$

Where, $\mathrm{FC}=$ fixed carbon percentage, $\mathrm{AC}=$ Percentage ash content, and $\mathrm{VM}=$ percentage volatile matter. The caloric value is measured by an oxygen bomb caloric meter. However due to the no availability of equipment we use literature to calculate the gross caloric value by using $\mathrm{MC}, \mathrm{VC}$, and $\mathrm{AC}$ that have already been calculated before. In our laboratory, we use MC, VC, and $\mathrm{AC}$ correlation to calculate the caloric heating value by this equation [15].

$\mathrm{GCV}=37.777-0.647 \quad$ MC-0.387AC-0.089VM

$\mathrm{R} 2=0.97$

Where MC is moisture content, $\mathrm{AC}$ is ash content, $\mathrm{VM}$ is volatile matter and $\mathrm{R}$ is the coefficient of determination. The proximate analysis was done for paper and starch in the same way as shown for the sawdust bonded charcoal briquette from the above.

\section{Results and Discussion}

The characterization was done for degradable solid waste and a charcoal briquette. Furthermore, its density, moisture content in percent, volatile matter content in percent, the content of ash, and content of fixed carbon and caloric heat value of degradable municipal solid wastes were determined. The physical and combustion properties of the charcoal briquettes examined in this work were limited to density, porosity index, shatter resistance, percentage moisture content, percentage volatile matter, percentage ash content, and fixed carbon percentage and calorific heat value.

\subsection{Proximate}

Density was determined by using equation -1 and aobtained as $16.73 \mathrm{~kg} / \mathrm{m}^{3}$. This implies the degradable municipal solid waste has low energy density therefore it is difficult to store for a long time. Thus it is advisable to increase the density of degradable solid waste by drying, carbonizing, and molding degradable municipal solid waste while using directly for charcoal briquette purposes. The moisture content of DMSW was determined by weighing 32 grams of the sample and drying it in the oven at $105^{\circ} \mathrm{C}$ until three hours or until the mass of a sample was constant $(5.7 \mathrm{~g})$. Moisture content of the sample was $18.15 \%$. It was determined using equation 3 . This shows degradable municipal solid waste has a high content of moisture and needs further drying before carbonization which is needed to lower the moisture content of this biodegradable municipal solid waste for charcoal briquette production. The content of volatile matter was computed as $66.95 \%$ using equation 3 . And the average value of $66.95 \%$ was recorded at $550^{\circ} \mathrm{C}$ for $10 \mathrm{~min}$.

Table 1. Proximate analysis for degradable solid waste

\begin{tabular}{ll}
\hline Properties & Numerical value \\
\hline Density & $16.73 \mathrm{~kg} / \mathrm{m}^{3}$ \\
Moisture content & $17.81 \%$ \\
Volatile matter & $67.56 \%$ \\
Ash content & $4.78 \%$ \\
Fixed carbon & $9.85 \%$ \\
Caloric value & $18.39 \mathrm{~kJ} / \mathrm{kg}$ \\
\hline
\end{tabular}

The highest value of volatile matter enhances the degradable municipal solid waste to be ignited easily. As compared with the volatile matter of charcoal briquettes it is too high. This is because of simply disintegration or unbounded degradable municipal solid waste. However, the structure of charcoal briquette is strongly bonded with binder Sawdust. The content of ash was calculated as the weight of ash divided by that of the weight of the dry sample and obtained as $4.07 \%$ at $900^{\circ} \mathrm{C}$ using equation 4 . This is smaller than the ash content of charcoal briquette and this variation is because of sawdust bound to charcoal briquette. In the fresh biodegradable municipal solid waste particle are not bonded to each other and this allows the adequate flow of oxygen in the internal part of in internal part of this waste. However, in the charcoal briquettes, particles are bonded to each other since sawdust added makes less ash content. The fixed carbon content percentage was found to be $9.85 \%$ using equation 5. The average fixed carbon content of biomass is fallen in the range of $9.78 \%-24.16 \%$. The total fixed carbon content obtained in this study is $9.85 \%$. This result may not fit the literature value range because our raw material contains high moisture content materials like food waste (fruits peel and spoiled vegetables) and other wet materials. Using equation 6 the heating caloric value of DMSW was calculated as $18.39 \mathrm{~kJ} / \mathrm{kg}$.

\subsection{Characterization of charcoal briquette}

The density of charcoal briquette was obtained as $750.06 \mathrm{~kg} / \mathrm{m}^{3}$ using equations 8 and 9 . This value implies that the charcoal briquettes obtained from degradable solid waste in our work have a high density as the compared density of wood charcoal, density of charcoal briquette produced from cane bagasse. The density of charcoal briquette bonded with sawdust give a density of $750.06 \mathrm{~kg} / \mathrm{m}^{3}$. The diameter of the mold or cylinder affects the density of charcoal briquettes. Porosity is defined as a measure of the void spaces in a material and is a fraction of the volume of voids over the total volume; it generally lies between $0-1 \mathrm{~mm}$. The porosity index is defined as the ratio of the weight of water absorbed divided by the dry http://dx.doi.org/10.22135/sje.2020.5.3.134-141

138 
weight of the sample briquette when immersed into water. A briquette with a higher porosity index has lower water resistance capacity. The porosity index was found as $29.05 \%$ by using equation 10 .

Table 2. summary of proximate analysis for charcoal briquette using sawdust as a binder

\begin{tabular}{ll}
\hline Properties & Value obtained \\
\hline Density & $750.06 \mathrm{~kg} / \mathrm{m}^{3}$ \\
Porosity index weight & $29.05 \%$ \\
Shatter resistance & $92.38 \%$ \\
Moisture content & $9.87 \%$ \\
Volatile matter & $29.60 \%$ \\
Ash content & $3.56 \%$ \\
Fixed carbon percentage & $56.97 \%$ \\
Caloric value & $27.38 \mathrm{MJ} / \mathrm{kg}$ \\
\hline
\end{tabular}

The above value of the porosity index obtained was existing between 0 and 1 that has low water resistance. Therefore if charcoal briquettes have a higher porosity index, it will absorb more water and will be disintegrated easily. The Shatter resistance was found to be $92.377 \%$ using equations 11 and 12 . The above values of shatter resistance obtained show high shatter resistance. This means that the reaction force of denser charcoal briquettes has higher shatter resistance than that of less dense charcoal briquettes when they are allowed to fall from $2 \mathrm{~m}$ height from top to the ground.

This leads to denser charcoal briquettes are more chance to lose part of it. Higher shatter resistance implies a lower weight loss and resistance to handling stress. Therefore charcoal briquette produced in our work has good durability. The moisture content of charcoal briquette was obtained as $9.87 \%$ by using equation 13.The above value of content moisture obtained in our work was fall in the percentage of 5-10\% according to Suksankraisorn $\mathrm{K}$ et al. [24]. The volatile matter of charcoal briquettes was found to be $29.4 \%$ by using equation 14.The above values of volatile matter obtained in our works are in the range of $20-30 \%$ according to literature a charcoal briquette with low volatile content tends to incomplete combustion which leads to an insignificant amount of smoke and release of toxic gas. The ash content was obtained as $3.56 \%$ by using equation 15 .

The above value of ash contents of charcoal briquettes obtained in our work is in the range of as compared to or as recommended in. Ash content for good quality charcoal briquettes is fall in the range of $3-4 \%$. Ash is an impurity that will not burn, fuels with high ash content are less suited for thermal utilization than fuels with high ash content. The higher ash content in fuel usually leads to higher dust emission. The value of fixed carbon for charcoal briquettes was obtained as $56.97 \%$ by

Vol. 5 No. 3, 134-141 using equation 16. This value of fixed carbon content is very low as compared with Wang $L$ et al. [26] that is from $70-75 \%$. Since the fixed carbon content is more related to the carbonation process, during the carbonation process we use manual made carbonizer equipment this may leak air to combust the raw material in a little manner. Fixed carbon positively correlated with carbon monoxide, with less fixed carbon contained in the charcoal briquettes gave less carbon monoxide and prolong cooking time by its low heat release. A lower fixed carbon, a better result during combustion, and a lesser probability of $\mathrm{CO}_{2}$ generation.

The charcoal Briquettes having much content of volatile matter have lower fixed carbon, which favors being harder, heavier, stronger, and easier to ignite than briquettes containing high fixed carbon. By using equation 17 we calculated GCV of charcoal briquette as $27.38 \mathrm{MJ} / \mathrm{Kg}$. The above caloric value of charcoal briquette produced from degradable municipal waste is higher than that of the caloric value of wood charcoal which is $8.27 \mathrm{MJ} / \mathrm{kg}$ and higher than charcoal briquette produced from bagasse which has a caloric value of 23.4 $\mathrm{MJ} / \mathrm{kg}$ according to different kinds of literature. The higher calorific value reflects the high quality of charcoal briquettes.

\subsection{Factors that affect the charcoal briquette}

The factor which affects fuel charcoal briquette includes the size of the particle, the diameter of the mold, and the type of binder used. The binder content affects the quality of charcoal briquettes by their amount. In our work, we use $25 \%$ of starch content to produce charcoal briquette. According to Borowski $G$ et al. [25] the charcoal briquettes that good quality was obtained at starch content from 25-30\%. Under this content of starch, the charcoal briquette shatters easily like during transportation.

Table 3. Summary of proximate analysis for charcoal briquette using waste paper as a binder

\begin{tabular}{ll}
\hline Properties & Value obtained \\
\hline Density & $712.08 \mathrm{~kg} / \mathrm{m}^{3}$ \\
Porosity index weight & $29.89 \%$ \\
Shatter resistance & $89.48 \%$ \\
Moisture content & $9.99 \%$ \\
Volatile matter & $30.65 \%$ \\
Ash content & $4.68 \%$ \\
Fixed carbon percentage & $56.97 \%$ \\
Caloric value & $27.38 \mathrm{MJ} / \mathrm{kg}$ \\
\hline
\end{tabular}

The particle size of this study raw material is $4 \mathrm{~mm}$. According to this particle size, the charcoal briquette was characterized for moisture content, density, volatile matter, ash content, fixed carbon percentage, the caloric value of $9.87 \%, 750.06 \mathrm{~kg} / \mathrm{m}^{3}, 29.6 \%, 3.56 \%, 56.97 \%$,

http://dx.doi.org/10.22135/sje.2020.5.3.134-141

139 
and $27.38 \mathrm{MJ} / \mathrm{kg}$ respectively. Therefore according to the different literature views charcoal briquettes that have good qualities were obtained at a size of a particle, not more than $4 \mathrm{~mm}$. The difference in diameters of the two cylinders could show variation characteristics of charcoal briquette. This shows the relationship between the property of charcoal and the diameter of the mold. For a small mold equipment diameter, fewer amounts of pores were obtained and have small shatter resistance. But at a large diameter of the mold or cylinder has high porosity index weight and high shatter resistance. The good charcoal is obtained for starch and sawdust used as a binder comparing with paper as a binder.

\subsection{Strength and weakness of the product}

The fuel charcoal briquette produced from degradable solid waste has good heating value as compared to charcoal briquette from wood and charcoal briquette produced from molasses. Some of the characterization properties of charcoal briquette tested in this work was fall in the range. Therefore it is recommended to convert solid wastes into charcoal briquette rather than polluting the environment. Due to the present atmospheric condition of Southwestern Ethiopia the product was loose some quality as compared with standard value since it requires sufficient sun to dry charcoal briquette. Fixed carbon content affected by the carbonization process performed in my work that was made manually is allowing the little amount of oxygen since the carbonizer has a hole at the bottom and top section.

Table 4: ummary of proximate analysis for charcoal briquette using starch as a binder

\begin{tabular}{ll}
\hline Properties & Value obtained \\
\hline Density & $750.06 \mathrm{~kg} / \mathrm{m}^{3}$ \\
Porosity index weight & $29.95 \%$ \\
Shatter resistance & $93.38 \%$ \\
Moisture content & $9.95 \%$ \\
Volatile matter & $29.50 \%$ \\
Ash content & $3.50 \%$ \\
Fixed carbon percentage & $56.57 \%$ \\
Caloric value & $27.59 \mathrm{MJ} / \mathrm{kg}$ \\
\hline
\end{tabular}

The characterization summary result for different binders (sawdust, paper, and starch) is tabulated with tables 2, 3, and 4 in the appendix part. The test result for density, the content of moisture, the content of volatile matter, the content of ash, the content of fixed carbon, and caloric value of degradable municipal solid waste was determined as $16.73 \mathrm{~kg} / \mathrm{m} 3,17.81 \%, 67.56 \%, 4.78 \%$, $9.85 \%$ and $18.39 \mathrm{MJ} / \mathrm{kg}$ respectively. In the same way, the test result of charcoal briquette using sawdust as a binder for its density, porosity weight index, shatter resistance,

Vol. 5 No. 3, 134-141 moisture content, volatile matter, ash content, fixed carbon content, and caloric values were obtained as $750.06 .06 \mathrm{Kg} / \mathrm{m} 3,29.05 \%, 92.38 \%, 9.87 \%, 29.6 \%$, $3.56 \%, 56.97 \%$, and $27.38 \mathrm{MJ} / \mathrm{kg}$, respectively.

\section{Conclusions}

This study involves the determination of the characteristics of degradable solid waste and the produced charcoal briquette using sawdust as a binder. The test was carried out for charcoal briquette using sawdust, starch, and paper as a binder for its density, porosity weight index, shatter resistance, moisture content, volatile matter, ash content, fixed carbon content, and calo ric values. Using sawdust as binder gave the results that are in the range comparing with other works of literature and close to the characteristics of using starch as a binder. Thus it is possible to convert Southwestern Ethiopia degradable solid waste into charcoal briquette using sawdust as a binder. As illustrated from the above the charcoal briquette produced had high density, moisture content that is typical, has high volatile content, has typical ash content, and low content for fixed carbon as relative to other charcoal briquette obtained from the different feedstock. Since sawdust can be used in place of starch as a binder as the test was observed from this research work. Besides waste paper can be used as a binder for charcoal briquette production. However, the charcoal briquette produced using waste paper as binder shows low density and a high percentage of ash. This work is aimed to help in the controlling of the solid waste and could be used as a tool for handling a decision towards waste generated daily in various activities of people in Southwestern Ethiopia.

\section{Acknowledgment}

The authors want to say thanks to Jimma University Institute of Technology School of Chemical Engineering lab technician Mr. Workineh Soressa and his colloquies for their dedication to helping me during laboratory work.

\section{References}

[1] Sachi, P.J., and Mensah, E.A., 2020. Household characteristics and waste generation paradox: what influences solid waste generation in Bolgatanga?. Int. J. Environment and Waste Management, 26(2).

[2] Dobsevage, S., Gibson, J.T., Helz, K., Planert, C., Prasartkul, A., Raye, K., Singh, A., and Wofsy, S., 2006. Meeting Basic Needs in a Rapidly Urbanizing Community: A Water, Sanitation, and Solid Waste Assessment in Ruiru, Kenya. New York, School of International and Public Affairs, Columbia University.

[3] Harper, M., 2004. Sustainable Composting: Case studies and guidelines for developing countries. WEDC, Loughborough University.

http://dx.doi.org/10.22135/sje.2020.5.3.134-141 
[4] Bayu, A.B., Amibo, T.A., and Akuma, D.A., 2020. Conversion of Degradable Municipal Solid Waste into Fuel Briquette: Case of Jimma City Municipal Solid Waste. Iranian (Iranica) Journal of Energy \& Environment, 11(2), pp.122-129.

[5] Tiwari, A., 2016. Urban Infrastructure Research: A Review of Ethiopian Cities. Springer International Publishing.

[6] Simon, D., 2013. Climate and environmental change and the potential for greening African cities. Local Economy, 28(2), pp.203-217.

[7] Humphrey, M.M., 2015. Development of biomass wastes briquette stove for domestic use (doctoral dissertation, kenyatta university).

[8] Chandrappa, R., and Das, D.B., 2012. Waste quantities and characteristics. In Solid waste management (pp. 47-63). Springer, Berlin, Heidelberg.

[9] Telmo, C., Lousada, J., and Moreira, N., 2010. Proximate analysis, backward stepwise regression between gross calorific value, ultimate and chemical analysis of wood. Bioresource technology, 101(11), pp.3808-3815.

[10] Sadef, Y., Nizami, A.S., Batool, S.A., Chaudary, M.N., Ouda, O.K.M., Asam, Z.Z., Habib, K., Rehan, M., and Demirbas, A., 2016. Waste-to-energy and recycling value for developing an integrated solid waste management plan in Lahore. Energy Sources, Part B: Economics, Planning, and Policy, 11(7), pp.569-579.

[11] Safe, A., Fernandez, A., Mazza, G., and Rodriguez, R., 2019. Prediction of regional agro-industrial wastes characteristics by thermogravimetric analysis to obtain bioenergy using the thermal process. Energy Exploration \& Exploitation, 37(1), pp.544-557.

[12] Xue, S., Zhang, X., Ngo, H.H., Guo, W., Wen, H., Li, C., Zhang, Y. and Ma, C., 2019. Food waste-based biochars for ammonia nitrogen removal from aqueous solutions. Bioresource technology, 292, p.121927.

[13] Xue, S., Zhang, X., Ngo, H.H., Guo, W., Wen, H., Li, C., Zhang, Y. and Ma, C., 2019. Food waste-based biochars for ammonia nitrogen removal from aqueous solutions. Bioresource technology, 292, p.121927.

[14] Hanaki, K., and Portugal-Pereira, J., 2018. The effect of biofuel production on greenhouse gas emission reductions. In Biofuels and Sustainability (pp. 53-71). Springer, Tokyo.

[15] Magwenzi, J., 2013. A study of household waste management behaviors in Hatfield and Sunningdale suburbs: Harare (Doctoral dissertation, Bindura University of Science Education).

[16] Tiwari, A., 2016. Urban Infrastructure Research: A Review of Ethiopian Cities. Springer International Publishing.
[17] Meena, M.D., Yadav, R.K., Narjary, B., Yadav, G., Jat, H.S., Sheoran, P., Meena, M.K., Antil, R.S., Meena, B.L., Singh, H.V. and Meena, V.S., 2019. Municipal solid waste (MSW): Strategies to improve salt-affected soil sustainability: A review. Waste management, 84, pp.38-53.

[18] Motghare, K.A., Rathod, A.P., Wasewar, K.L., and Labhsetwar, N.K., 2016. Comparative study of different waste biomass for energy application. Waste management, 47, pp.40-45.

[19] Bayu, A.B., Amibo, T.A., and Akuma, D.A., 2020. Conversion of Degradable Municipal Solid Waste into Fuel Briquette: Case of Jimma City Municipal Solid Waste. Iranian (Iranica) Journal of Energy \& Environment, 11(2), pp.122-129.

[20] Sotannde, O.A., Oluyege, A.O., and Abah, G.B., 2010. Physical and combustion properties of charcoal briquettes from neem wood residues. International Agrophysics, 24(2), pp.189-194.

[21] Roberts, J.J., Cassula, A.M., Prado, P.O., Dias, R.A. and Balestieri, J.A.P., 2015. Assessment of dry residual biomass potential for use as an alternative energy source in the party of General Pueyrredón, Argentina. Renewable and Sustainable Energy Reviews, 41, pp.568-583.

[22] Zhang, J., and Guo, Y., 2014. Physical properties of solid fuel briquettes made from Caragana korshinskii Kom. Powder Technology, 256, pp.293-299.

[23] Ikelle, I.I., and Ogah, S.P.I., 2014. Determination of the heating ability of coal and corn cob briquettes. IOSR Journal of applied chemistry (IOSRJAC) e-ISSN, pp.2278-5736.

[24] Suksankraisorn, K., Patumsawad, S., and Fungtammasan, B., 2003. Combustion studies of high moisture content waste in a fluidized bed. Waste Management, 23(5), pp.433-439.

[25] Borowski, G., Stępniewski, W., and Wójcik-Oliveira, K., 2017. Effect of starch binder on charcoal briquette properties. International Agrophysics, 31(4), p.571.

[26] Wang L, Skreiberg, Gronli M, Specht GP, Antal Jr MJ. Is elevated pressure required to achieve a high fixed-carbon yield of charcoal from biomass? Part 2: The importance of particle size. Energy \& fuels. 2013 Apr 18;27(4):2146-56.

[27] García R, Pizarro C, Lavín AG, Bueno JL. Characterization of Spanish biomass wastes for energy use. Bioresource technology. 2012 Jan 1;103(1):249-58. 